\title{
Diffuse Alveolar Hemorrhage After Intravenous Thrombolysis for Acute Ischemic Stroke
}

\author{
Akut İskemik Ínmede İntravenöz Tromboliz Sonrası Diffüz Alveoler Kanama
}

Keywords: Diffuse alveolar hemorrhage, thrombolysis, stroke

Anahtar Kelimeler: Diffüz alveoler kanama, tromboliz, inme

\section{Dear Editor,}

A 37-year-old left-handed woman was brought to the Emergency Department 90 minutes after acute-onset left hemiplegia and global aphasia. Her medical history revealed that she had mitral stenosis and atrial fibrillation for several years. No medications including blood thinners were reported. The initial neurologic examination revealed left hemiplegia, global aphasia, and left gaze preference. A National Institutes of Health Stroke Score of 19 points was recorded. Initial brain computed tomography (CT) excluded bleeding. The CT scan showed a hyperdense abnormality within the proximal right middle cerebral artery (MCA) (Figure 1). CT angiography of the cervical vessels was reported as normal. The initial laboratory findings were within normal limits. The cause of stroke was accepted as cardioembolism due to valvular atrial fibrillation. After obtaining consent, the patient was transferred to the stroke unit for treatment; we infused a standardized protocol of intravenous-recombinant tissue-plasminogen activators (IV-rt-PA) at 2.5 hours after symptom onset with no medical improvement in return. A follow-up brain CT scan at the $24^{\text {th }}$ hour showed a large ischemic lesion demonstrating right MCA M1 occlusion in the right hemisphere (Figure 2).

Twelve hours after the rt-PA treatment, the patient gradually developed dyspnea, cough, hypoxemia, and hemoptysis. A chest X-ray revealed bilateral alveolar infiltrates (Figure 3). The patient underwent endotracheal intubation for mechanical ventilation. Chest X-ray and chest CT on the next day showed bilateral diffuse alveolar infiltrates (Figure 4). The hemoglobin level dropped from $11.6 \mathrm{~g} / \mathrm{dL}$ to $8.2 \mathrm{~g} / \mathrm{dL}$. Diffuse alveolar hemorrhage was suspected and confirmed after a pulmonary

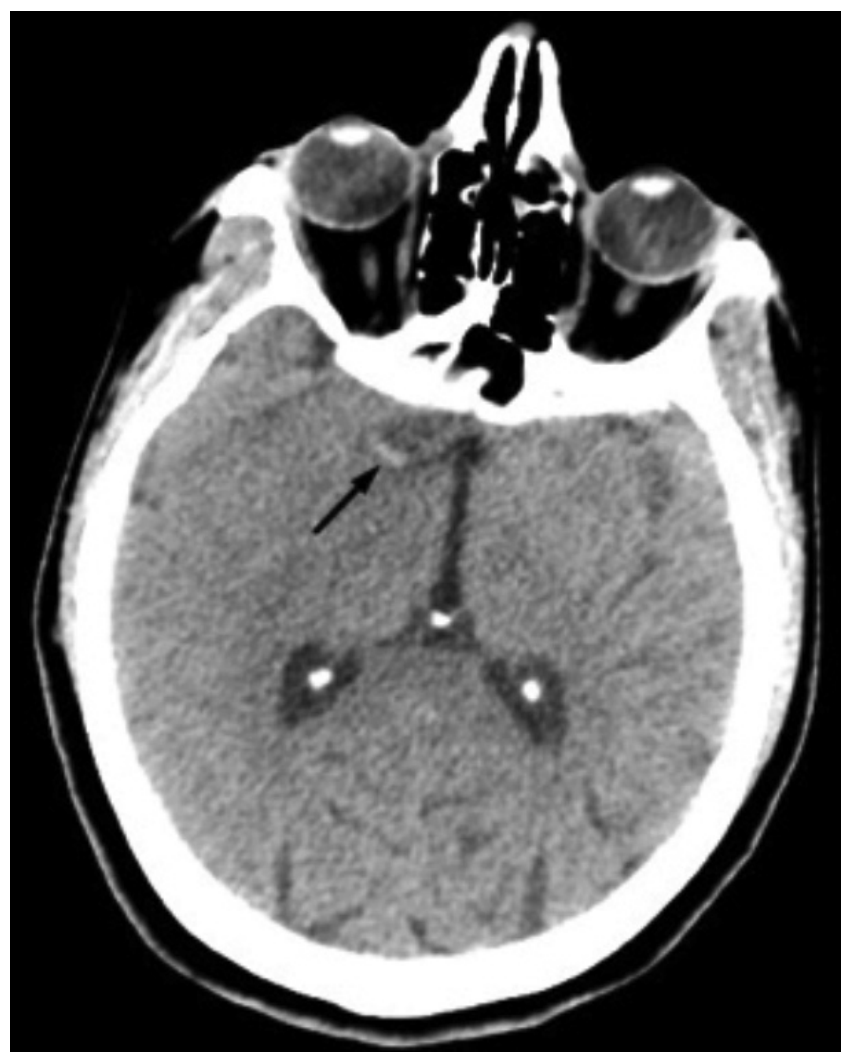

Figure 1. Initial non-contrast head computed tomography with hyperdense middle cerebral artery sign (arrow)

Address for Correspondence/Yazışma Adresi: Özcan Kocatürk MD, Harran University Faculty of Medicine, Department of Neurology, Sanliurfa, Turkey Phone: +905074191621 E-mail: ozcankocaturk@gmail.com ORCID: orcid.org/0000-0002-9693-4451

Received/Geliş Tarihi: 18.01.2019 Accepted/Kabul Tarihi: 26.04.2019 


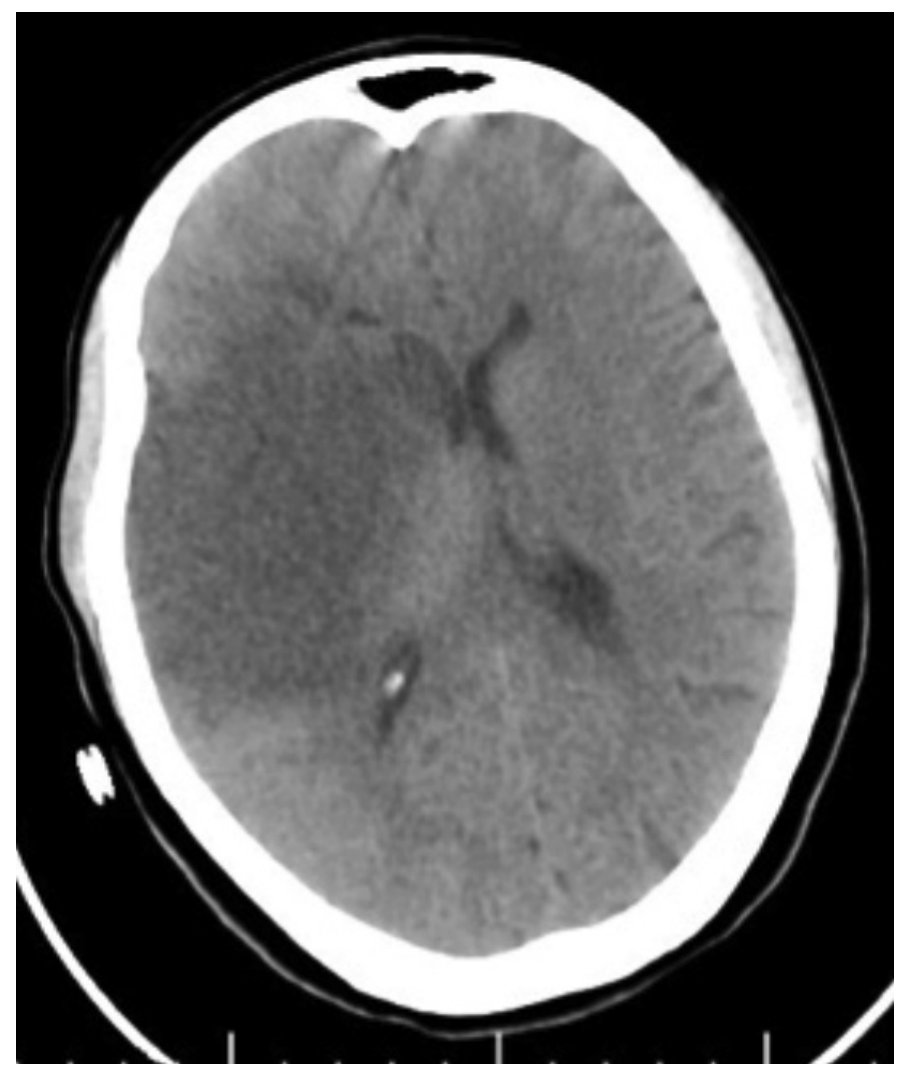

Figure 2. Control non-contrast head computed tomography one day later demonstrates large ischemic lesion

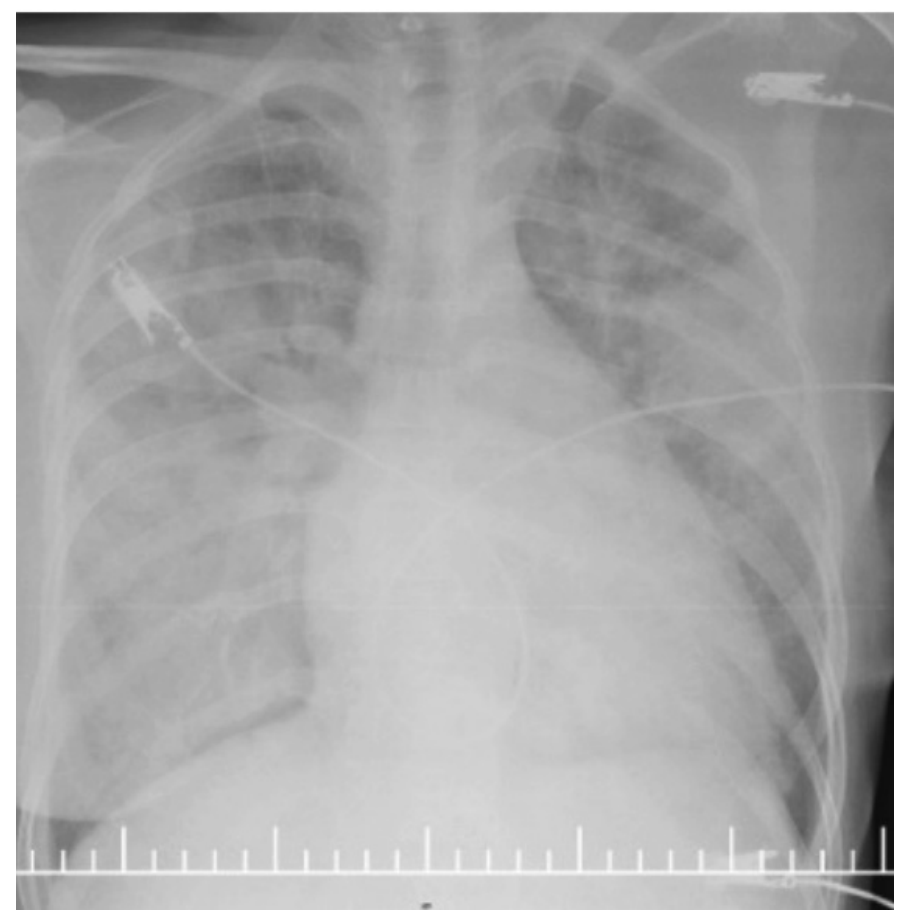

Figure 3. Chest X-ray posteroanterior view shown bilateral alveolar infiltrate

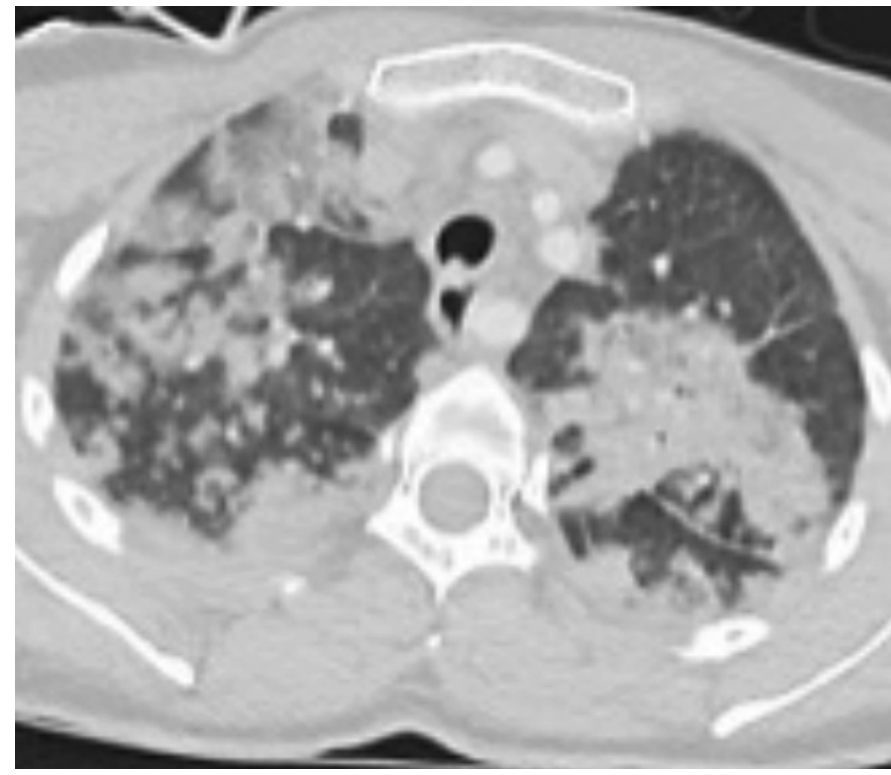

Figure 4. Chest computed tomography two day later after rt-PA administration demonstrates diffuse alveolar infiltrates

medicine consultation. She received 4 units of fresh frozen plasma and 2 units of packed red cells. The patient remained intubated and on mechanical ventilation for 10 days. Follow-up chest CT and X-ray imaging taken after one month showed complete resolution of the infiltrates. The patient was transferred to the palliative care unit at one month after administration with a modified Rankin scale score of 5 .

Diffuse alveolar hemorrhage is a very rare, life-threatening complication of iv. lytic therapy and should be considered in patients with hemoptysis, pulmonary infiltrates, and acute anemia after thrombolysis (1). There are some reports related to alveolar hemorrhage with thrombolytic therapy after myocardial infarction $(2,3)$. This is the first case of pulmonary alveolar hemorrhage in a patient with stroke after thrombolytic therapy.

The exact incidence of this complication is unknown. It usually occurs within a few hours to five days after the thrombolytic treatment. There are some predisposing factors related to intra-alveolar hemorrhage including immunodeficiency, pneumonia, chronic obstructive pulmonary disease, congestive heart failure, and tobacco and cocaine use $(3,4)$. In our patient, hemoptysis started 12 hours after the treatment and none of abovementioned predisposing factors existed. On the other hand, the patient had atrial fibrillation and mitral stenosis associated with rheumatic fever. The presence of alveolar bleeding in this patient might be related to valvular atrial fibrillation.

Management of diffuse alveolar hemorrhage consists of treatment of respiratory failure and anemia (5). Sometimes respiratory failure may require ventilation, as the anemia requires transfusion of packed cells. Our patient required mechanical ventilation for 10 days, and packed red cell transfusions were given twice. 
Ethics

Informed Consent: Written informed consent was received from the patient for publication of this report and accompanying images.

Peer-review: Externally peer-reviewed.

\section{Authorship Contributions}

Surgical and Medical Practices: H.A., Concept: M.K., Design: M.K., Data Collection or Processing: H.A., Analysis or Interpretation: Ö.K., Literature Search: Ö.K., Writing: M.K.

Conflict of Interest: There is no conflicts of interest in this report.

Financial Disclosure: The authors declared that this study received no financial support.

\section{References}

1. Prabhakaran S, Ruff I, Bernstein RA. Acute Stroke Intervention. JAMA 2015;313:1451-1562.

2. Narayanan S, Thulaseedharan NK, Subramaniam G, Panarkandy G, Arathi N. Pulmonary alveolar hemorrhage following thrombolytic therapy. Int Med Case Rep J 2017;10:123-125.

3. Mahjoob MP, Khaheshi I, Paydary K. Diffuse pulmonary hemorrhage after fibrinolytic therapy for acute myocardial infarction in a cocaine abuser patient. Heart Views 2014;15:83-85.

4. Nathan PE, Torres AV, Smith AJ, Gagliardi AJ, Rapeport KB. Spontaneous pulmonary hemorrhage following coronary thrombolysis. Chest 1992;101:1150-1152.

5. Rabe C, Appenrodt B, Hoff C, et al. Severe respiratory failure due to diffuse alveolar hemorrhage: clinical characteristics and outcome of intensive care. $\mathrm{J}$ Crit Care 2010;25:230-235. 